\title{
CHARACTERISTICS OF IN VITRO SEED GERMINATION OF THREE BASIL GENOTYPES UNDER DIFFERENT NUTRITION
}

\author{
Dragana Jakovljević, Biljana Bojović*, Milan Stanković, Marina Topuzović \\ University of Kragujevac, Faculty of Science, Department of Biology and Ecology, \\ Radoja Domanovića 12, 34000 Kragujevac, Serbia \\ *Corresponding author; E-mail: biljana.bojovic@pmf.kg.ac.rs
}

(Received April 29, 2020; Accepted May 5, 2020)

\begin{abstract}
The present study was designed to investigate the effects of different basal medium composition on germination characteristics in three basil genotypes under in vitro conditions. Ocimum basilicum var. basilicum cv. Genovese, Ocimum basilicum var. purpurascens cv. Dark Opal and Ocimum x citriodorum seeds were grown in media with a quarter, half, and full-strength of macro- and micronutrients and under different levels of nitrate alone or in combination with different levels of ammonium. Evaluated parameters included germination percentage, mean time to germination, rate of germination, and germination uniformity. Seeds of the studied basil genotypes demonstrated significant differences in germination characteristics depending on the availability of nutrients, but also the nitrogen form used. It was concluded that in order to obtain a high level of germinated seeds with significant speed and uniformity of germination under in vitro conditions culture media composition must be adjusted according to the investigated genotype. The results of this study could improve overall tissue culture conditions for a particular basil genotype.
\end{abstract}

Keywords: basil, genotype, germination, nitrogen, tissue culture.

\section{INTRODUCTION}

Plant tissue culture systems supply all necessary nutrients, water, and energy for plant growth through the basal medium and allow maintenance of whole plants, as well as organs, tissues, or cells under aseptic controlled laboratory conditions. Numerous investigations in this field formed two main distinct trends - efforts to optimize the basal medium for specific species or genotypes and screening large numbers of in vitro germinated seedlings for a particular genotype (PHILLIPS and GARDA, 2019).

Seed germination and consequent elongation of radicle and hypocotyl are among the most significant stages of the life cycle of the plant. The time frame for the duration of the germination process (from the moment of passive water uptake to seed coat decomposition and the appearance of radicle) is genetically conditioned, but the differentiation of embryos and zygotes in this phase is very sensitive to environmental conditions (CHACÓN et al., 2013). Although desiccated seeds are generally resistant to the stressful conditions, germinating 
seeds are not, and consequently requiring defensive strategies to stressful conditions in order to ensure survival. The answer to these conditions depends on the type and intensity of the stress, as well as the plant species and genotype (MACOVEI et al., 2017). Prevention of stressful conditions during the germination period and development of young seedlings is a very important aspect for the successful production of economically significant plant species (BALABUSTA et al., 2016). However, one of the basic problems encountered during the cultivation process is control of mineral nutrition conditions in basal medium, which further may result in an unsuccessful plant tissue system, so unless mineral nutrition conditions are clearly defined, nutritional stress can lead to significant losses (DA SILVA et al., 2017).

One of the most important elements of mineral nutrition in plants is nitrogen. Nitrogen is a constituent of amino acids and proteins and it regulates the enzyme activities required for energy metabolism (HUSSAIN et al., 2016). Plant growth depends on an appropriate supply of nitrogen in order to synthesize the amino acids, nucleic acids, and other cellular constituents which are further necessary for plant development (SÁNCHEZ et al., 2004). Nitrate $\left(\mathrm{NO}_{3}{ }^{-}\right.$) and ammonium $\left(\mathrm{NH}_{4}{ }^{+}\right)$are primary nitrogen sources (SUNG et al., 2015) and plants produce visible changes in their growth and development if growing on the medium containing nitrate or ammonium under deficit or excess (POLESSKAYA et al., 2006). In recent years there is an increased interest in ammonium-based nutrition due to the high energy cost of nitrate absorption and assimilation, however, this form of nutrition is been reported as stressful to many important crops and may trigger oxidative imbalance in plants (JAKOVLJEVIĆ et al., 2017). Additionally, it is very difficult to differentially quantify $\mathrm{NO}_{3}{ }^{-} / \mathrm{NH}_{4}{ }^{+}$utilization in tissue culture media when both nitrate and ammonium are simultaneously available to plants (ZHANG et al., 2019).

The cultivation of the species from the genus Ocimum L. (basil) has been intensified globally, because of their pharmaceutical and nutritional importance as well as their long-term traditional use and wide range of adaptability at different soil types and climatic conditions. Among applications in the food industry, basil plants are valuable sources of essential oils and phenolic compounds with significant antioxidant, antimicrobial, cytotoxic and other biological activities (JAKOVLJEVIĆ et al., 2019). The alterations of characteristics in basil plants due to cultivation conditions raising the need to develop a system that is true to type, effective, and enable reproducible plant screening (SRIVASTAVA et al., 2014).

In the present paper, three different basil genotypes Ocimum basilicum var. basilicum cv. Genovese, Ocimum basilicum var. purpurascens cv. Dark Opal and hybrid Ocimum x citriodorum have been tested in order to study the effects of different basal medium composition and nitrogen source on in vitro germination characteristics. The results of this study may provide valuable information about the nutrient management regime for basil tissue culture and can contribute to a better yield of this important crop plant.

\section{MATERIALS AND METHODS}

\section{Plant material and experimental design}

The seeds of three basil cultivars were used in this study: green-leaved Genovese basil (Ocimum basilicum var. basilicum cv. Genovese), purple-leaved Dark Opal basil (Ocimum basilicum var. purpurascens cv. Dark Opal), and lemon basil (Ocimum x citriodorum). Seeds were obtained from commercial sources ("Semesemena", Belgrade). Since it was demonstrated that basil physiological responses under tissue culture conditions depend on the type and straight of the media, as well as cultivar used (JAKOVLJEVIĆ et al., 2017; 2019) this experiment was designed to investigate genotype-related differences in the first week of in vitro growth of basil cultivars under different mineral nutrition. The surface sterilization of seeds 
was done with a method that does not affect seed germination (JAKOVLJEVIĆ et al., 2017). After sterilization single seed was inoculated in a $25 \mathrm{ml}$ volumetric glass tube containning 10 $\mathrm{ml}$ of appropriate media.

Based on mineral element concentration, three types of media were used: full (1), half $(1 / 2)$, and a quarter (1/4) of strength, respectively. The full-strength media consisted of following elements: $1 \mathrm{mM} \mathrm{NaH}_{2} \mathrm{PO}_{4}, 1 \mathrm{mM}\left(\mathrm{NH}_{4}\right)_{2} \mathrm{SO}_{4}, 1 \mathrm{mM} \mathrm{MgSO} \mathrm{m}_{4} \times 7 \mathrm{H}_{2} \mathrm{O}, 1 \mathrm{mM} \mathrm{CaCl}_{2}$ x $2 \mathrm{H}_{2} \mathrm{O}, 0.05 \mathrm{mM} \mathrm{H}_{3} \mathrm{BO}_{3}, 0.005 \mathrm{mM} \mathrm{KJ}, 0.06 \mathrm{mM} \mathrm{MnSO}_{4}$ x $4 \mathrm{H}_{2} \mathrm{O}, 0.04 \mathrm{mM} \mathrm{ZnSO}_{4}$ x $7 \mathrm{H}_{2} \mathrm{O}$, $0.1 \mu \mathrm{M} \mathrm{CuSO}_{4} \times 5 \mathrm{H}_{2} \mathrm{O}, 1 \mu \mathrm{M} \mathrm{Na}_{2} \mathrm{MoO}_{4} \times \mathrm{H}_{2} \mathrm{O}, 1 \mu \mathrm{M} \mathrm{CoCl}_{2} \times 6 \mathrm{H}_{2} \mathrm{O}, 0.1 \mathrm{mM} \mathrm{FeSO}_{4} \times 7 \mathrm{H}_{2} \mathrm{O}$, $0.1 \mathrm{mM} \mathrm{Na} 2 \mathrm{EDTA}$ and $3 \%$ sucrose. In the $1 / 2$ media concentrations of macronutrients and micronutrients were half of the strength, whereas in the $1 / 4$ media quarter of strength, respectively. For these media two types of nitrogen form were applied - one with nitrate as the main nitrogen source (media $a$ ), and other with a combination of nitrogen and ammonia (media $b$ ) as the following: $1 a$ - full-strength media with $24.7 \mathrm{mM} \mathrm{KNO}_{3} ; 1 / 2 a$ - halfstrength media with $12.36 \mathrm{mM} \mathrm{KNO}_{3} ; 1 / 4 \mathrm{a}$ - quarter-strength media with $6.18 \mathrm{mM} \mathrm{KNO}_{3} .1 b$ - full strength media with $18.8 \mathrm{mM} \mathrm{KNO}_{3}$ and $20.6 \mathrm{mM} \mathrm{NH}_{4} \mathrm{NO}_{3} ; 1 / 2 b$ - half strength media with $9.4 \mathrm{mM} \mathrm{KNO}_{3}$ and $10.3 \mathrm{mM} \mathrm{NH}_{4} \mathrm{NO}_{3} ; 1 / 4 b$ - quarter strength media with $4.7 \mathrm{mM}$ $\mathrm{KNO}_{3}$ and $5.15 \mathrm{mM} \mathrm{NH}_{4} \mathrm{NO}_{3}$.

All media were supplemented with $7 \mathrm{~g} / \mathrm{l}$ agar. The $\mathrm{pH}$ of all media was adjusted to 5.7-5.8 before autoclaving $\left(121{ }^{\circ} \mathrm{C}, 15 \mathrm{~min}\right)$. After seed inoculation, the cultures were incubated in a plant growth chamber at $25 \pm 2{ }^{\circ} \mathrm{C}$ at $60 \%$ relative humidity and $16 / 8 \mathrm{~h}$ photoperiod (cool-white fluorescent lamps with the irradiance of $70 \mu \mathrm{m} \mathrm{m}^{-2} \mathrm{~s}^{-1}$ ).

\section{Germination characteristics}

For every media used at least 200 seeds were inoculated and the results were obtained after three repetitions. Seeds were considered germinated after radicle appearance (at least 2 $\mathrm{mm}$ ). The recording of sprouted seeds was done daily until the number of germinated seeds was constant. Germination percentage (GP), the mean time for germination (MTG), rate of germination (RG) and germination uniformity (U) were calculated according to ESPANANY et al. (2016) and FERNANDEZ et al. (2015) based on the following equations:

\section{Germination percentage (GP)}

$$
\mathrm{GP}=\frac{\text { Total number of germinated seeds }}{\text { Total number of planted seeds }} \times 100
$$

Mean Time to Germination (MTG)

$$
\mathrm{MTG}=\sum n_{i} \mathrm{x} t_{i} / \sum n_{i}
$$

$n_{i}=$ number of newly germinated seeds in the time $i$

$t_{i}=$ time from the start of experiment to the observation (in days).

Rate of Germination (RG)

$\mathrm{RG}=\sum G / t$

$G=$ the percentage of seed germination at one day intervals and $t$ is the total germination period.

Germination uniformity

$\mathrm{U}=\mathrm{GP} / \mathrm{MTG}$ 


\section{Statistical analysis}

Data are presented as mean \pm S.E. (standard error) of three measurements. The program SPSS v.20 for Windows was used for the statistical evaluation of the results with an analysis of variance (ANOVA) and Tukey's multiple range tests $(p \leq 0.05)$.

\section{RESULTS AND DISCUSSION}

Nitrate and ammonium are the main sources of nitrogen for crop plants, and when it comes to the tissue cultures, nitrogen is generally supplied as $\mathrm{NO}_{3}{ }^{-}$at concentrations close to $10 \mathrm{mM}$ (KIFERLE et al., 2014; ZERVOUDAKIS et al., 2015). However, the extreme levels of nitrogen and other main nutrients can lead to toxicity symptoms and consequently to the death of plants. When it comes to basil germination studies, the in vitro culture technique can be useful since it does not compromise future growth and seedling development, especially in prolonged studies. The seeds from basil genotypes investigated in this study were capable to germinate and to develop seedling in different nutrient conditions, still, these processes demonstrated significant differences.

\section{Ocimum basilicum var. basilicum cv. Genovese}

The results obtained by examining the germination characteristics of "Genovese" basil indicate a significant effect of mineral nutrition on the development of Ocimum basilicum var. basilicum cv. Genovese during the first week (Tab. 1). The highest percentage of germination $(\mathrm{GP}=89.36 \%)$ was observed for full strength media with nitrate alone (1a). However, a statistically significant difference was found between this media and full-strength media with nitrate and ammonium, since the presence of ammonium in the media significantly reduced the germination percentage $(\mathrm{GP}=78.82 \%)$. The $1 \mathrm{a}$ media is also a treatment in which the seeds of Ocimum basilicum var. basilicum cv. Genovese showed the highest germination rate $(\mathrm{RG}=73.06)$. However, the highest degree of germination uniformity $(\mathrm{U}=35.70)$, as well as the fastest germination (MTG $=2.49)$ was achieved in half-strength media with nitrate $(1 / 2 \mathrm{a})$, while significantly slower germination was observed in the presence of ammonium.

\section{Ocimum basilicum var. purpurascens cv. Dark Opal}

The first week of in vitro germination of the genotype Ocimum basilicum var. purpurascens cv. Dark Opal is accompanied by significant differences in germination characteristics regarding the concentration of mineral elements and the form of available nitrogen in basal medium. The results are presented in Tab. 2. The highest percentage of germinated seeds $(\mathrm{GP}=93.75 \%)$ was observed in the treatment with the minimum concentration of mineral elements and the nitrate form of nitrogen (1/4a media), and the results indicate that the increase in the concentration of mineral elements decreases the percentage of total germinated seeds. Opposite, ammonium presence and high nutrient content significantly reduced the germination percentage with the lowest values under full strength media with ammonium (GP = $64.91 \%$ ). Although there are no statistically significant differences in the rate of germination between the media used, the lowest RG values were obtained at the highest nutrient concentrations. The highest and the lowest percentages of germinated seeds were followed by the highest and the lowest uniformity of germination $(U=31.99$ for $1 / 4$ a treatment; $U=22.46$ for $1 \mathrm{~b}$ treatment). When it comes to the rate of germination, there are no significant differences between the media used, whereas the seeds germinated faster under half strength media with nitrogen $(\mathrm{MTG}=2.73)$. 
Table 1. Germination characteristics of the genotype Ocimum basilicum var. basilicum cv. Genovese at different nutrient concentrations and different nitrogen sources in basal medium.

\begin{tabular}{ccccc}
\hline & \multicolumn{4}{c}{ Germination characteristics } \\
\cline { 2 - 5 } Medium & GP & MTG & RG & U \\
\hline 1/4a & $78.72 \pm 1.24 \mathrm{a}$ & $2.54 \pm 0.07 \mathrm{a}$ & $61.40 \pm 0.69 \mathrm{a}$ & $30.99 \pm 1.12 \mathrm{ac}$ \\
$\mathbf{1 / 2 a}$ & $88.89 \pm 0.89 \mathrm{~b}$ & $2.49 \pm 0.06 \mathrm{a}$ & $68.89 \pm 0.78 \mathrm{a}$ & $35.70 \pm 1.01 \mathrm{~b}$ \\
$\mathbf{1 a}$ & $89.36 \pm 1.31 \mathrm{~b}$ & $2.60 \pm 0.11 \mathrm{a}$ & $73.06 \pm 0.74 \mathrm{a}$ & $34.37 \pm 0.99 \mathrm{ab}$ \\
$\mathbf{1 / 4 b}$ & $87.50 \pm 1.31 \mathrm{ab}$ & $2.64 \pm 0.31 \mathrm{a}$ & $66.96 \pm 1.18 \mathrm{a}$ & $33.14 \pm 0.48 \mathrm{ab}$ \\
$\mathbf{1 / 2 b}$ & $85.11 \pm 1.46 \mathrm{ab}$ & $2.78 \pm 0.16 \mathrm{~b}$ & $63.52 \pm 0.87 \mathrm{a}$ & $30.62 \pm 0.89 \mathrm{c}$ \\
$\mathbf{1 b}$ & $78.82 \pm 1.26 \mathrm{a}$ & $2.86 \pm 012 \mathrm{~b}$ & $57.75 \pm 0.61 \mathrm{a}$ & $27.52 \pm 1.02 \mathrm{c}$ \\
\hline
\end{tabular}

The results are presented as the mean of three independent measurements \pm standard error.

Different letters indicate significant differences $(\mathrm{p}<0.05)$ between treatments based on Tukey-test.

Table 2. Germination characteristics of the genotype Ocimum basilicum var. purpurascens cv. Dark Opal at different nutrient concentrations and different nitrogen sources in basal medium.

\begin{tabular}{ccccc}
\hline & \multicolumn{4}{c}{ Germination characteristics } \\
\cline { 2 - 5 } Medium & GP & MTG & RG & U \\
\hline 1/4a & $93.75 \pm 1.43 \mathrm{ad}$ & $2.93 \pm 0.22 \mathrm{ab}$ & $67.86 \pm 1.22 \mathrm{a}$ & $31.99 \pm 0.54 \mathrm{a}$ \\
1/2a & $83.33 \pm 1.13 \mathrm{bd}$ & $2.73 \pm 0.25 \mathrm{a}$ & $65.37 \pm 0.83 \mathrm{a}$ & $30.52 \pm 0.56 \mathrm{a}$ \\
1a & $78.26 \pm 0.95 \mathrm{bc}$ & $2.81 \pm 0.29 \mathrm{a}$ & $60.33 \pm 1.28 \mathrm{a}$ & $27.85 \pm 0.74 \mathrm{a}$ \\
1/4b & $89.66 \pm 1.39 \mathrm{~d}$ & $2.94 \pm 0.23 \mathrm{~b}$ & $62.39 \pm 1.03 \mathrm{a}$ & $30.49 \pm 0.27 \mathrm{a}$ \\
1/2b & $79.49 \pm 1.21 \mathrm{be}$ & $3.08 \pm 0.24 \mathrm{~b}$ & $68.97 \pm 0.94 \mathrm{a}$ & $25.81 \pm 0.45 \mathrm{~b}$ \\
1b & $64.91 \pm 1.14 \mathrm{f}$ & $2.89 \pm 0.19 \mathrm{a}$ & $51.27 \pm 0.79 \mathrm{a}$ & $22.46 \pm 0.99 \mathrm{~b}$ \\
\hline
\end{tabular}

The results are presented as the mean of three independent measurements \pm standard error.

Different letters indicate significant differences $(\mathrm{p}<0.05)$ between treatments based on Tukey-test.

\section{Ocimum x citriodorum}

"Lemon" basil genotype is characterized by the highest percentage of total germinated seeds, since in each basal medium used the percentage of germinated seeds was greater than $90 \%$ (Tab. 3). The highest percentage of germinated seeds was observed in media $1 / 4 \mathrm{~b}$ (GP = $97.78 \%$ ) and was statistically significant from all other basal media used. The medium with the highest germination percentage is also the medium with the most uniformed germination $(\mathrm{U}=42.70)$. In addition, significant uniformity in germination is achieved by applying $1 / 2 \mathrm{a}$ media ( $U$ = 40.92), while in other media used significantly lower values of uniformed germination were observed. The most suitable treatment for achieving rapid and uniformed germination was half strength media with nitrate (in media $1 / 2 \mathrm{a} M T G=2.24$ ). The highest rate of germination is also measured with the application of this medium $(R G=74.31)$, significantly different from other media used._Similarly, rapid $(\mathrm{MTG}=2.29$ ) and uniformed germination $(U=42.70)$ was noted for $1 / 4 b$ treatment. 
Table 3. Germination characteristics of the genotype Ocimum x citriodorum at different nutrient concentrations and different nitrogen sources in basal medium.

\begin{tabular}{ccccc}
\hline & \multicolumn{4}{c}{ Germination characteristics } \\
\cline { 2 - 5 } Medium & GP & MTG & RG & U \\
\hline $\mathbf{1 / 4 a}$ & $91.11 \pm 0.19 \mathrm{a}$ & $2.41 \pm 0.13 \mathrm{a}$ & $66.67 \pm 1.27 \mathrm{a}$ & $37.80 \pm 0.45 \mathrm{ac}$ \\
$\mathbf{1} / \mathbf{2 a}$ & $91.67 \pm 0.26 \mathrm{a}$ & $2.24 \pm 0.11 \mathrm{~b}$ & $74.31 \pm 1.61 \mathrm{~b}$ & $40.92 \pm 1.13 \mathrm{abd}$ \\
$\mathbf{1 a}$ & $91.49 \pm 0.41 \mathrm{a}$ & $2.60 \pm 0.14 \mathrm{c}$ & $62.13 \pm 1.14 \mathrm{a}$ & $35.19 \pm 1.25 \mathrm{ce}$ \\
$\mathbf{1} / \mathbf{4 b}$ & $97.78 \pm 0.68 \mathrm{~b}$ & $2.29 \pm 0.10 \mathrm{a}$ & $72.11 \pm 1.23 \mathrm{a}$ & $42.70 \pm 1.18 \mathrm{~d}$ \\
$\mathbf{1} / \mathbf{2 b}$ & $90.91 \pm 0.49 \mathrm{a}$ & $2.42 \pm 0.15 \mathrm{a}$ & $71.21 \pm 1.13 \mathrm{a}$ & $37.57 \pm 0.89 \mathrm{ae}$ \\
$\mathbf{1 b}$ & $91.30 \pm 1.07 \mathrm{a}$ & $2.44 \pm 0.15 \mathrm{a}$ & $71.61 \pm 0.98 \mathrm{a}$ & $37.42 \pm 0.35 \mathrm{ae}$ \\
\hline
\end{tabular}

The results are presented as the mean of three independent measurements \pm standard error.

Different letters indicate significant differences $(\mathrm{p}<0.05)$ between treatments based on Tukey-test.

Seeds of the studied basil genotypes show significant differences in germination characteristics depending on the availability of nutrients, but also the nitrogen form used. Among tested genotypes, seeds of the hybrid genotype Ocimum x citriodorum showed the highest germination percentage (almost 98\%) at a minimal nutrient concentration and under ammonium presence. The seeds of Ocimum basilicum var. purpurascens cv. Dark Opal germinated in the highest percentage at a minimum concentration of nutrients, but without ammonium and under nitrate as the only nitrogen source. Opposite, Ocimum basilicum var. basilicum cv. Genovese seeds germinated in the highest percentage in full strength basal medium with nitrate alone. However, the total germination of seeds only reflects the ability of seeds to germinate, without the indications of speed, synchronization, and rate of germination, i.e. to the vital factors that must be involved in the characterization of the seed, not just with horticultural and agronomic points, but in order to define physiological, technological and environmental characteristics (AL-MUDARIS, 1998; RANAL and SANTANA, 2006; MAVI et al., 2010; FERNANDEZ et al., 2015). Overall, high nutrient content, especially with the presence of ammonium-nitrate, significantly affects the germination with the genotype-dependent manner. Inappropriate concentration and composition of the basal medium may induce delay of germination, reduction of germination speed, dynamic, and uniformity of germination. The variations in germination characteristics of different basil varieties under various conditions are demonstrated earlier (JAKOVLJEVIĆ et al., 2017; NOORHOSSEINI et al., 2017).

Mean germination time, a significant indicator of emergence, can be defined as the length of lag germination phase from the beginning imbibition to the penetration of the radicle (MAVI et al., 2010). Since MTG represents the mean time from germination initiation to its completion, a lower MTG value represents faster germination (FERNANDEZ et al., 2015). According to MTG, tested genotypes demonstrated the following order: Ocimum basilicum var. purpurascens cv. Dark Opal < Ocimum basilicum var. basilicum cv. Genovese < Ocimum x citriodorum, whereby MTG of Ocimum basilicum var. purpurascens cv. Dark Opal and Ocimum basilicum var. basilicum cv. Genovese was significantly longer in the presence of $\mathrm{NH}_{4} \mathrm{NO}_{3}$. Opposite to the MTG, higher values of rate of germination indicate faster germination (FERNANDEZ et al., 2015). According to this parameter, the same order is observed: Ocimum basilicum var. purpurascens cv. Dark Opal < Ocimum basilicum var. basilicum cv. Genovese < Ocimum x citriodorum, and, in general, the germination rate is lower when the seeds germinate in the presence of $\mathrm{NH}_{4} \mathrm{NO}_{3}$. Uniformity germination indicates variability among seeds over the mean time germination of samples (RANAL and SANTANA, 2006). The same trend in germination uniformity for tested genotypes was observed as in the case of MTG and RG. 
Regardless of the requirements that individual genotypes have in terms of nutrient concentration, and in relation to achieving the best germination characteristics, it has been shown that when the basil seeds are in contact with different concentrations of $\mathrm{NH}_{4} \mathrm{NO}_{3}$ the germination process is significantly affected. The effects of the presence of ammonium ions have been demonstrated by PÈREZ-FERNÀNDEZ et al. (2006), and the authors suggested a significant delay of the germination process with the treatment including $\mathrm{NH}_{4} \mathrm{NO}_{3}$. Positive effects of $\mathrm{KNO}_{3}$ on germination processes are shown in the case of in vitro culture of smallleaved basil genotype $O$. basilicum var. minimum (JAKOVLJEVIĆ et al., 2017).

Based on the results obtained in this investigation, it can be concluded that seeds of the studied basil genotypes show significant differences in germination characteristics depending on the availability of nutrients, but also the nitrogen form used. Although different modifications of basal media are available from commercial sources, for many plant species or different types of tissue culture, it is necessary to prepare media using individual chemicals and chemical components as stock solutions, and it is very important to create a reproducible media for diverse genotypes. The results of this study provide information's regarding the best basal medium composition and concentration for three basil genotypes for rapid and uniform germination and could improve overall tissue culture conditions for this valuable plant.

\section{Acknowledgments}

This investigation was supported by the Ministry of Education, Science and Technological Development of the Republic of Serbia (Agreement No. 451-03-68/2020-14/200122).

\section{References:}

[1] AL-Mudaris, M.A. (1998): Notes on various parameters recording the speed of seed germination. Der Tropenlandwirt-Journal of Agriculture in the Tropics and Subtropics 99 (2): 147-154.

[2] Balabusta, M., Szafranska, K., PosmyK, M.M. (2016): Exogenous melatonin improves antioxidant defense in cucumber seeds (Cucumis sativus L.) germinated under chilling stress. Frontiers in Plant Science 287 (7): 575. doi: 10.3389/fpls.2016.00575.

[3] Chacón, I.D.L.C., Riley-SaldaÑa, C.A., GonZÁlez-Esquinca, A.R. (2013): Secondary metabolites during early development in plants. Phytochemistry Reviews 12 (1): 47-64. doi: 10.1007/s11101-012-9250-8

[4] DA Silva, D.M., DE Souza, K.R.D., BoAs, L.V.V., Alves, Y.S., Alves, J.D. (2017): The effect of magnesium nutrition on the antioxidant response of coffee seedlings under heat stress. Scientia Horticulturae 224: 115-125. doi: 10.1016/j.scienta.2017.04.029

[5] Espanany, A., Fallah, S., TAdayyon, A. (2016): Seed priming improves seed germination and reduces oxidative stress in black cumin (Nigella sativa) in presence of cadmium. Industrial Crops and Products 79: 195-204. doi: 10.1016/j.indcrop.2015.11.016

[6] Fernandez, I.C.D., LuQue, E.G., Mercado, F.G., Marrero, J.M. (2015): Germination responses of Limonium insigne (Coss.) Kuntze to salinity and temperature. Pakistan Journal of Botany 47: 807-812.

[7] Hussain, S., Khan, F., CaO, W., Wu, L., Geng, M. (2016): Seed priming alters the production and detoxification of reactive oxygen intermediates in rice seedlings grown under sub-optimal temperature and nutrient supply. Frontiers in Plant Science 7: 439. doi:10.3389/fpls.2016.00439. 
[8] Jakovljević, D., Stanković, M., Bojović, B., Topuzović, M. (2017): Regulation of early growth and antioxidant defense mechanism of sweet basil seedlings in response to nutrition. Acta Physiologiae Plantarum 39 (11): 243. doi: 10.1007/s11738-017-2548-9

[9] Jakovljević, D., Topuzović, M., Stanković, M. (2019): Nutrient limitation as a tool for the induction of secondary metabolites with antioxidant activity in basil cultivars. Industrial Crops and Products 138: 111462. doi: 10.1016/j.indcrop.2019.06.025

[10] Kiferle, C., Lucchesini, M., Maggini, R., Pardossi, A., Mensuali-Sodi, A. (2014): In vitro culture of sweet basil: gas exchanges, growth, and rosmarinic acid production. Biologia Plantarum 58 (4): 601-610. doi: 10.1007/s10535-014-0434-5

[11] Macovei, A., Pagano, A., Leonetti, P., Carbonera, D., Balestrazzi, A., Araújo, S.S. (2017): Systems biology and genome-wide approaches to unveil the molecular players involved in the pre-germinative metabolism: implications on seed technology traits. Plant Cell Reports 36 (5): 669-688. doi: 10.1007/s00299-016-2060-5

[12] MAVI, K., DeMIR, I., MATTHEWS, S. (2010): Mean germination time estimates the relative emergence of seed lots of three cucurbit crops under stress conditions. Seed Science and Technology 38: 14-25. doi: 10.15258/sst.2010.38.1.02

[13] NoORhosseini, S.A., JoKAR, N.K., DAmalas, C.A. (2017): Improving seed germination and early growth of garden cress (Lepidium sativum) and basil (Ocimum basilicum) with hydro-priming. Journal of Plant Growth Regulation 37 (1): 323-334.

doi: 10.1007/s00344-017-9728-0

[14] Pèrez-Fernàndez, M.A., Calvo-Magro, E., Montanero-Fernández, J., OYola-VeLASCO, J.A. (2006): Seed germination in response to chemicals: effect of nitrogen and $\mathrm{pH}$ in the media. Journal of Environmental Biology 27 (1): 13-20.

[15] PhILLIPS, G.C., GARDA, M. (2019): Plant tissue culture media and practices: an overview. In Vitro Cellular and Developmental Biology-Plant 55 (3): 242-257. doi: 10.1007/s11627-019-09983-5

[16] Polesskaya, O.G., KashiRinA, E.I., AleKhinA, N.D. (2006): Effect of salt stress on antioxidant system of plants as related to nitrogen nutrition. Russian Journal of Plant Physiology 53: 186-192. doi: 10.1134/S1021443706020063

[17] Ranal, M.A., SANTANA, D.G.D. (2006): How and why to measure the germination process? Brazilian Journal of Botany 29 (1): 1-11. doi: 10.1590/S0100-84042006000100002

[18] SÁnchez, E., Rivero, R.M., Ruiz, J.M., Romero, L. (2004): Changes in biomass, enzymatic activity and protein concentration in roots and leaves of green bean plants (Phaseolus vulgaris L. cv. Strike) under high $\mathrm{NH}_{4} \mathrm{NO}_{3}$ application rates. Scientia Horticulturae 99 (3-4): 237-248. doi: 10.1016/S0304-4238(03)00114-6

[19] SRivastava, S., Cahill, D.M., Conlan, X.A., Adholeya, A. (2014). A novel in vitro whole plant system for analysis of polyphenolics and their antioxidant potential in cultivars of Ocimum basilicum. Journal of Agricultural and Food Chemistry 62 (41): 1006410075. doi: 10.1021/jf502709e

[20] Sung, J., LeE, S., LeE, Y., Ha, S., Song, B., Kim, T., Waters, B.M., Krishnan, H.B. (2015): Metabolomic profiling from leaves and roots of tomato (Solanum lycopersicum L.) plants grown under nitrogen, phosphorus or potassium-deficient condition. Plant Science 241: 55-64. doi: 10.1016/j.plantsci.2015.09.027

[21] Zervoudakis, G., Salahas, G., Maria, R.O.D.I. (2015): Nitrogen nutrition effect on aeroponic basil (Ocimum basilicum L.) catalase and lipid peroxidation. Notulae Botanicae Horti Agrobotanici Cluj-Napoca 43 (2): 561-567. doi: 10.15835/nbha43210181

[22] ZHANG, K., Wu, Y., HANG, H. (2019): Differential contributions of $\mathrm{NO}_{3}{ }^{-} / \mathrm{NH}_{4}{ }^{+}$to nitrogen use in response to a variable inorganic nitrogen supply in plantlets of two Brassicaceae species in vitro. Plant Methods 15: 86. doi: 10.1186/s13007-019-0473-1 